VOL. 24, NO. 4

Error Distributions in Navigation

E. W. Anderson And D. M. Elits

Air Traffic Control Separation Standards and Navigation

Air Traffic Control Separation Minima and Navigational Capability A. White

Mathematical Studies on Separation Standards

D. E. LLOYD

A Preliminary Analysis of Navigational Performance Observed at

Strumble 1969-1970

C. M. BRITLAND

The Potential of Existing Avionics Technology

S. RatCliffe

Polar Navigation-A New Transverse Mercator Technique G. C. DYER

Simplified Methods of Position Fixing Using Earth Satellites

T. M. B. WRIGHT

Sea-ice Pressure Generation and its Effect on Navigation in the

Gulf of St. Lawrence Area

J. D. BRADFORD

Studies in Marine Traffic Engineering

Traffic Surveys in Japan

A. Yamaguchi AND S. SAKaki

The Analysis of Traffic Accidents

Y. FuJII AND R. SHIOBARA

Traffic Capacity

Y. FUJII AND K. TANAKA

\title{
FORUM
}

Controlling Shipping Along the North European Trade Axis

D. J. LINDSAY

A Note on Manning Reductions and Navigation J. KING

'The Master in Changing Times'

D. BREEDVELD

Yaw Angles and Coriolis

P. H. TANNER

Terrain Clearance During Descent and Approach

J. D. PROCTOR

Gaussian Logarithms and Navigation

C. H. CotreR

THE INSTITUTE OF NAVIGATION

AT THE ROYAL GEOGRAPHICAL SOCIETY I KENSINGTON GORE LONDON SW

JOHN MURRAY (PUBLISHERS) LTD., 50 ALBEMARLE STREET, LONDON $w_{1}$ 


\title{
THE INSTITUTE OF NAVIGATION
}

\author{
Patron \\ H.R.H. THE PRINCE PHILIP DUKE OF EDINBURGH, x.G., к.T., о.м.
}

\section{OFFICERS AND COUNCIL 1970-71}

President

Rear Admiral G. S. Ritchie, c.B., D.s.c.

\author{
Vice-Presidents
}

G. E. Beck

Group Captain D. F. H. Grocott, C.B.E., A.F.C., R.A.F.

\section{Honorary Treasurer}

F. A. Haworth

\section{Chairman of the Technical Committee}

H. E. Smith

Chairman of the Membership and Fellowship Committee

Captain V. A. M. Hunt, c.B.E.

\author{
J. H. Beattie \\ W. J. Charnley \\ Captain C. H. Cotter \\ Captain R. Hart, c.B.E., \\ D.s.o., D.s.c*., R.N. (ret.)
}

S. S. D. Jones
Other Members of Council
Captain F. L. Main
Captain R. Maybourn
P. G. Reich
R. B. Richardson
R. Whalley

Executive Secretary: M. W. Richey, M.B.E.

\section{The Journal of the Institute of Navigation}

THE Journal is published quarterly by the Institute and is edited by M. W. RrCHEY. It contains original papers contributing to the science of navigation, including those presented at meetings of the Institute together with the ensuing discussion. In addition the Journal includes a record of current navigational work, reviews of important books, and other matters of concern to those interested in navigation. The views expressed in the Journal are not necessarily those of the Institute, or of any organization or department to which the authors may belong. Crown Copyright may be reserved.

The Journal is issued free to all members of the Institute. It is sold to the public at one pound fifty per copy or, by subscription, at six pounds thirty-five per annum (post free) and may be obtained through all booksellers and John Murray (Publishers) Ltd., 50 Albemarle Street, London W $W_{1}$. Back numbers dated two years prior to the current volume may be obtained from William Dawson \& Sons, Ltd., (Back Issues Department), Cannon House, Folkestone, Kent.

Enquiries for advertising space should be addressed to the Institute offices.

The postal address of the Institute is The Institute of Navigation, at The Royal Geographical Society, I Kensington Gore, London SW7. (Telephone: $01-5895021$ ).

Volumes of the Journal can be bound for one pound fifty. The parts should be sent to William Clowes \& Sons Ltd., Dorland House, 14 \& 16 Lower Regent Street, London SW.r. 


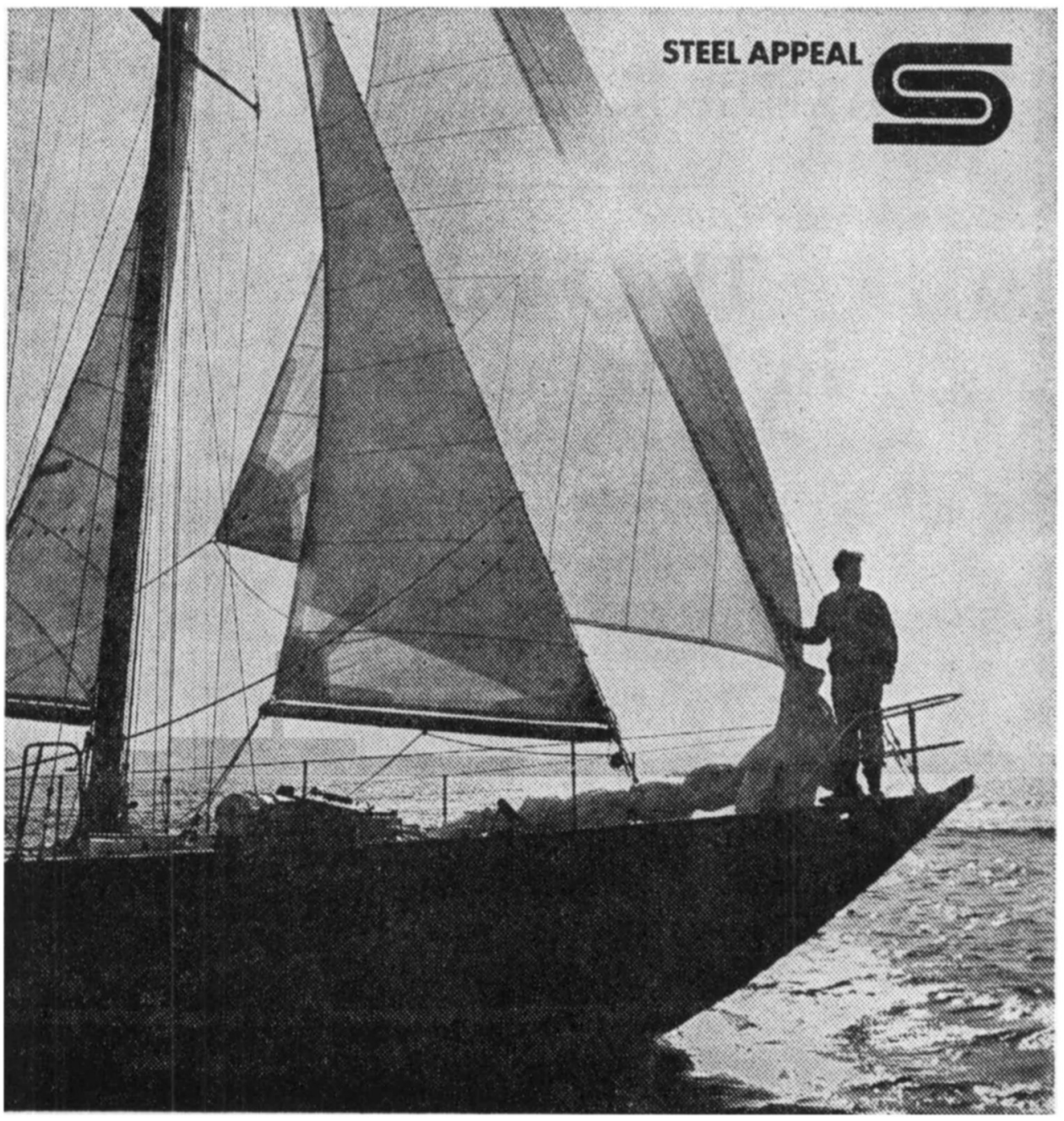

-Britsh Sted' designed by Robert Clark. Built by Philip \& Son, Dartmouth. Length $59 \mathrm{ft}$. Beam 12 ft. 10 ins. Draught 8 ft. Rig: Bermidian Ketch.

\section{"The steel people made it all possible" -Chay Blyth}

A 30 -year-old ex-paratrooper wanted to build a steel boat to sail round the world single-handed the mrong may. Against the wind.

Chay Blyth believed the odds were against him when he put his proposition to the British Steel Corporation. But BSC saw that a superbly designed and built steel yacht, sailing against some of the most daunting seas in the world, would be a brilliant testimonial for British steel, and Britain.

And now, Chay Blyth and his steel yacht have astonished the world. They have made the first-ever solo non-stop circumnavigation from East to West, in the amazing time of 292 days - the longest windward sail in history. And both man and boat have returned as fresh as the day they left.

\section{What 'British Steel' is made of}

HULL: Mild steel plate to L.loyd's Grade A specification.

FRAMES AND DECK BEAMS:

Mild steel sections.

DECK PLATES: Mild steel.

COCKPIT AND 'DOG-HOUSE':

Stainless steel (non-magnetic).

STANDING RIGGING:

Stainless steel wire rope.

British Steel Corporation 


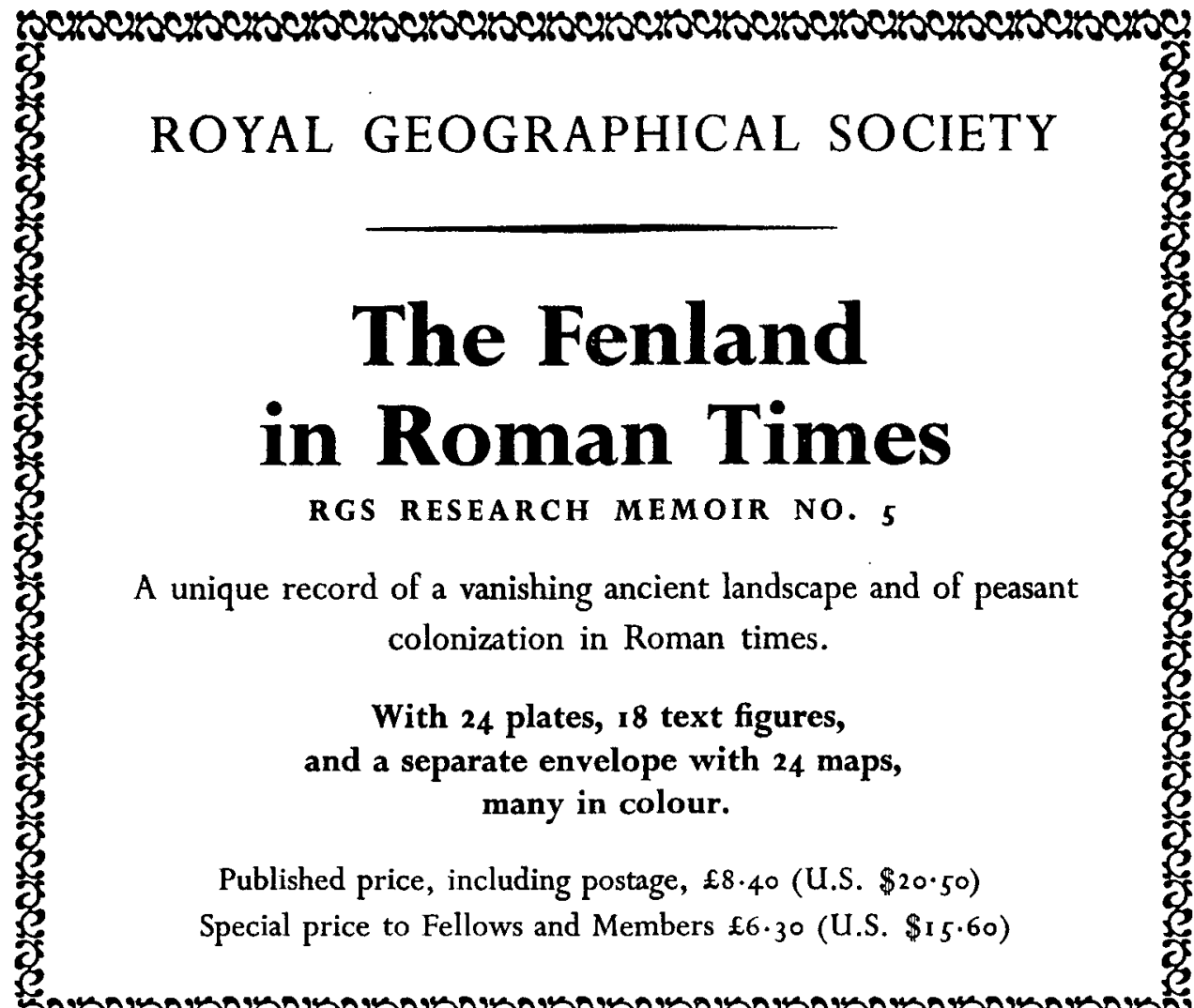

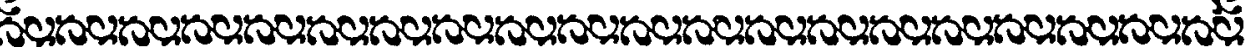

\section{MARINE OBSERVER}

A quarterly journal of maritime meteorology prepared by the Marine Division of the Meteorological Office, containing articles on weather, currents, ice conditions, meteorological observing at sea, and the practical use of a knowledge of meteorology to seamen. A large part of each issue is devoted to reports of meteorological and other scientific phenomena which have been contributed by voluntary observing ships.

Published in January, April, July, October, by Her Majesty's Stationery Office. $42 \frac{1}{2}$ p (by post $45 p$ ) per issue; annual subscription $£ 1.88$ including postage

Available from the Government Bookshops in London, (post orders to PO Box 569, SE1 9NH), Edinburgh, Cardifi, Belfast, Manchester, Birmingham and Bristol, or through booksellers 


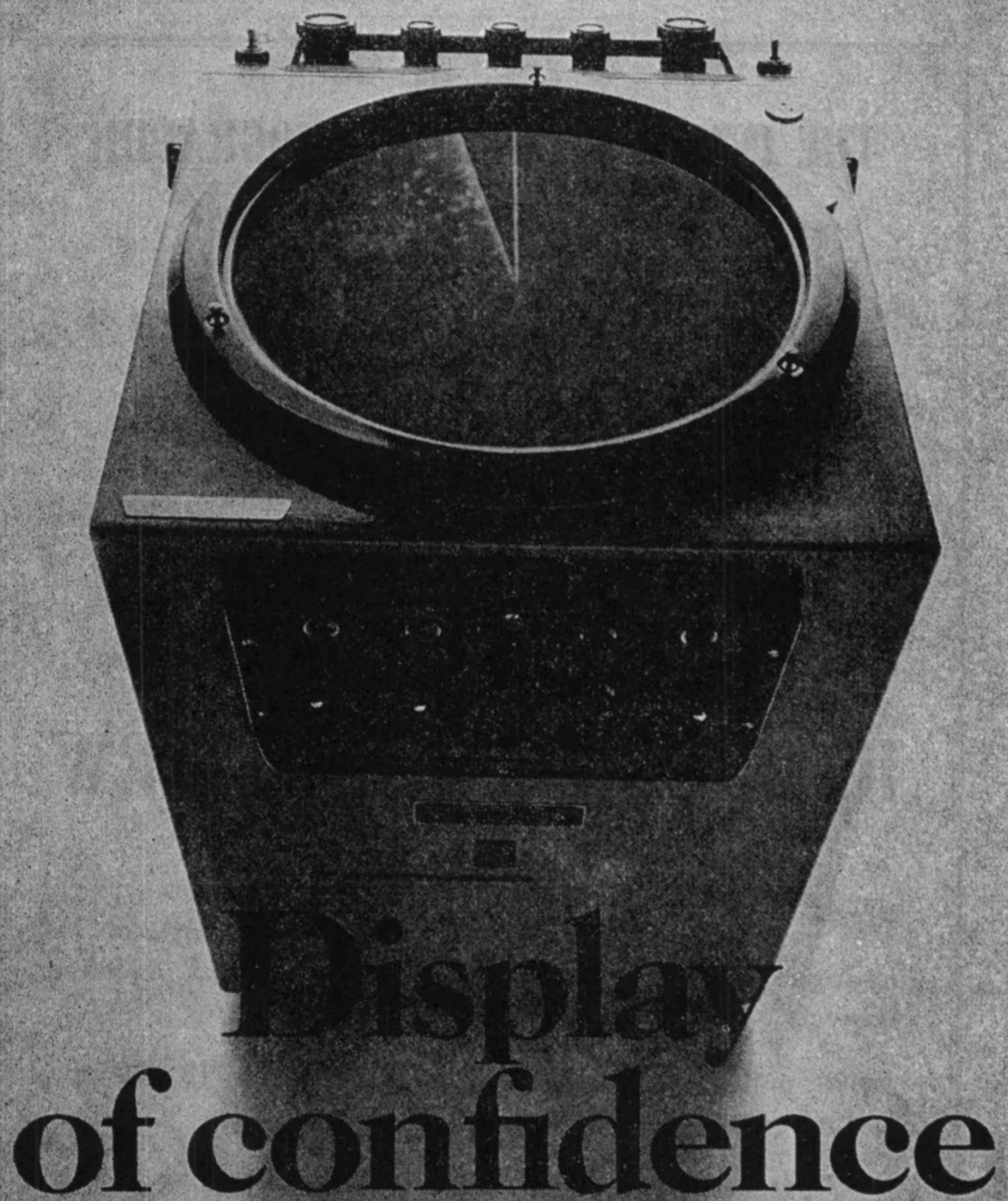

Confidently, we invite you to see the brightest, clearest radar display. The Kelvin Hughes Series 19. Ask us to show you its ten range scales, trom mile to 64 miles.

Its improyed chitter stuppression. Ifs $3 \mathrm{~cm} X$ band or $10 \mathrm{~cm} S$ baud uperation on 9 or 12 displays - with a range discrimiuation hetter than 10 yards ( 9 metres). For the price, there's nothing ta match it.

\section{Ast for a demonstration}

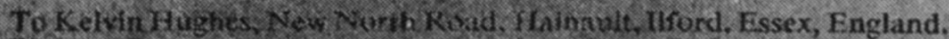
Please call me to arringe a demunstraned of y our Series 19 radar.

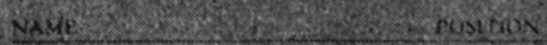

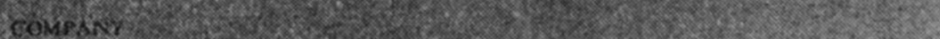
Ambios 


\title{
THE NTERNATIONAL HYDROGRAPHIC. BUREAU
}

\section{Avenue Président J. F. Kennedy, MONACD}

\author{
publishes
}

twice a year in January and July, an English and a French edition of

\section{THE INTERNATIONAL HYDROGRAPHIC REVIEW}

This publication containg articles of topical interest on hydrography, hydrographic surveying and related subjects.

Each number contains an average of 160 pages, $18 \times 27 \mathrm{~cm}$, and numerous illustrations.

Price per number $£ 2.50$ or $\$ 6$ (U.S.), plus postage.

Orders should be sent direct to the Bureau's Headquarters in Monaco, but payments can be made to the Bureau's account at Barclays Bank Ltd., Chief Foreign Branch, 152-156 Upper Thames Street; London, E.C.3. Specify English or French edition when ordering.

A reduction of $25 \%$ on the price quoted is allowed to booksellers. A reduction of $30 \%$ is granted to naval or merchant marine officers of IHO Member Governments, provided the order is sent direct to the Bureau. 


\section{tsperrey rano}

\section{SPERRY INTEGRATED SHIPS SYSTEMS}

The most comprehensive range of equipment ever offered

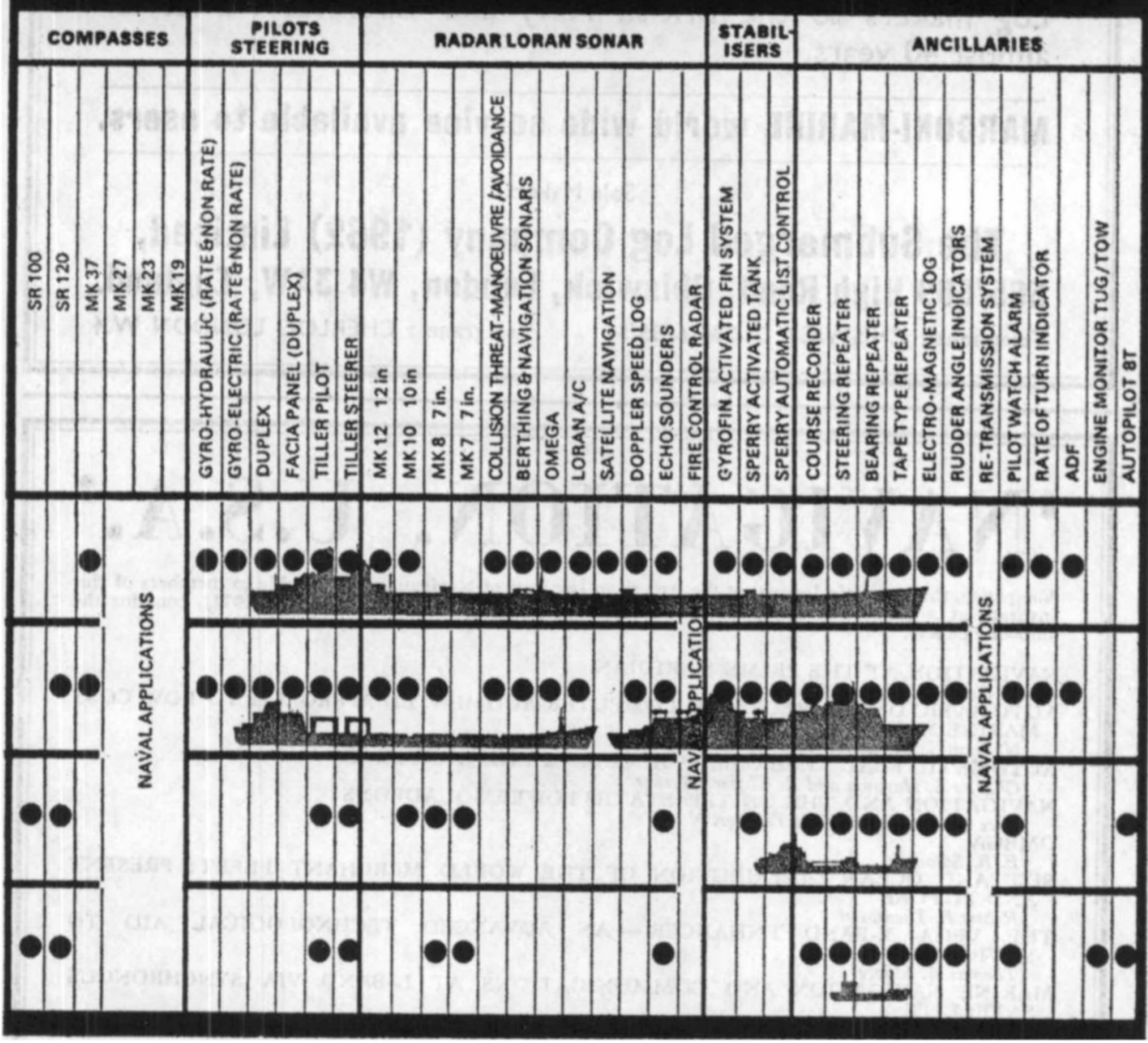

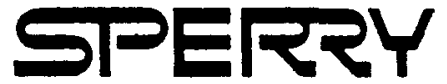

MARINE SYSTEMS DIVISION BRACKNELL BERKSHIRE ENGLAND 


\section{'Electronic Chernikeeff'}

Accurate and dependable at all speeds down to 1 -knot and distance run to within $1 \%$.

Suitable for Ship's Side or Bottom mounting-equal accurocy.

Lineor Speed Analog Voltage Transmission available direct from Log.

Has built-in Transmission for 'True-motion' Radar.

Low installation costs-simple mointenance.

The Retractable Log Tube can be provided remotely controlled from the Wheelhouse.

The ideal Log for all Mercantile Vessels-backed by over 50 years actual experience in the design and manufacture of Impeller Logs.

Log makers to the British Navy and Overseas Navies for almost 40 years.

MARCONI-MARINE world wide service available to users.

Sole Makers
The Submerged Log Bompany (1962) Limited,
565/569 High Road, Chiswick, London, W4 3AW, England.
Telephone: CHISWICK 01-994 6685/6 Telegrams: CHERLOG LONDON W.4

\section{'NAVIGATION, U.S.A.'}

Navigation, the quarterly Journal of the American Institute of Navigation, is available to members of this

Navigation, the quarterly Journal of the American Institute of Navigation, is available to members of this
Institute at a reduced subscription of $\complement 2$ a year. Volume 18, No. 2 (Summer 1971), contains the following papers.

\section{NAVIGATION AT THE PRIME MERIDIAN}

$G$ Gebel and $B$. Matheres
UTOMATIC OMEGA RECEIVER : COMPUTER-AUGMENTED APPROACH TO LOW COST

MARINE NAVIGATION

AUTOMATIC REAL TIME OMEGA ACCURACY ENHANCEMENT

Charles $E$. Hastings and $A$. Clifford Barker

NAVIGATION AND THE UNITED STATES POWER SQUADRONS

Vice Commander Herbert Talboys, $N$

OMEGA

B. R. Seranson

SIZE AND OCEAN DISTRIBUTION OF THE WORLD MERCHANT FLEET: PRBSENT AND FUTURB

Robert $P$. Thompson

THE VEGA X-BAND ENHANCER - AN ADVANCED TECHNOLOGICAL AID TO NAVIGATION

Thomas A. Moore

MARINE NAVIC

SATELLITE

INCAS INTEGRATED NAVIGATION AND COLLISION.AVOIDANCE SYSTEM

K. H. Chase and B.V. Tiblin

AUTOMATION OF MERCHANT SHIP NAVIGATION SYSTEMS

Thomas D. Mara

LOW COST AUTOMATIC SHIP POSITIONING AND GUIDANCE SYSTEM

L. Commander David $H$. Freesc, Jr., USCG

WHEN IS A BOAT SAFE?

Commander Willian $N$. Spence, USCO

Commander Wiliam $N$. Spence, USCG

Caleb Wamer and Peter Leavite

IMPROVED POSITION LOCATOR (IPL) A MAN CARRIED NAVIGATION SYSTEM W. H. Hoff

LOCAL HOUR ANGLE OF ARIES TABLES

Frederick L. Devereux, Yr. 


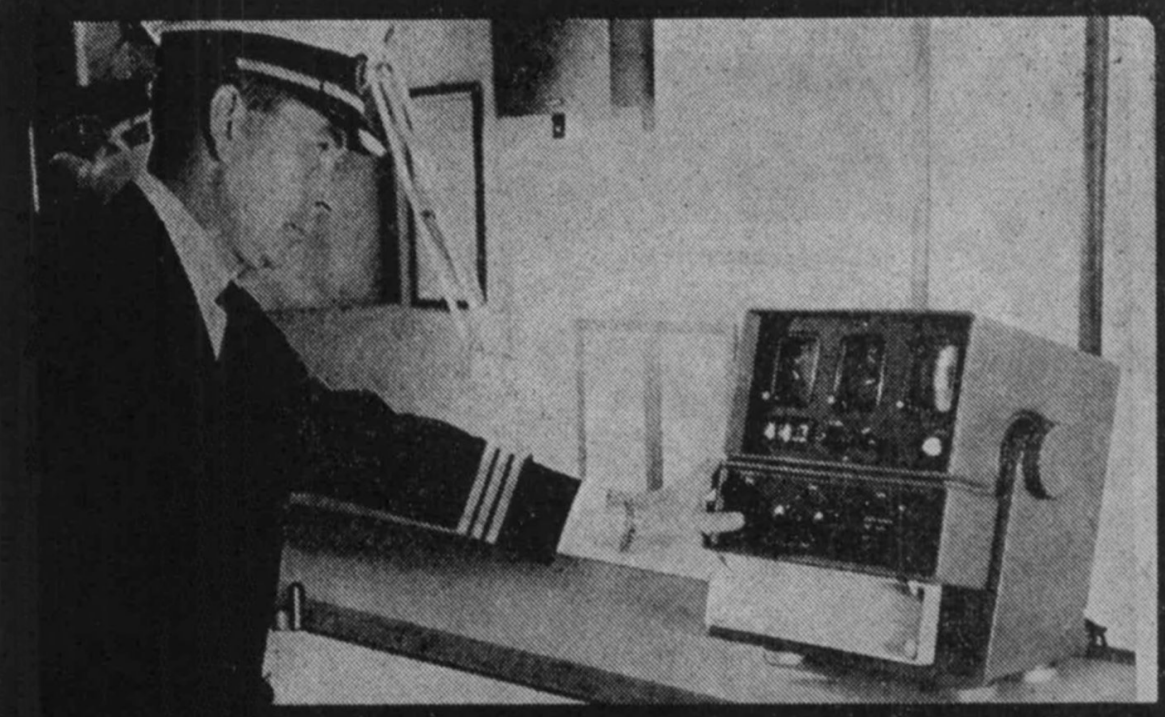

\section{Relied upon throughout the world}
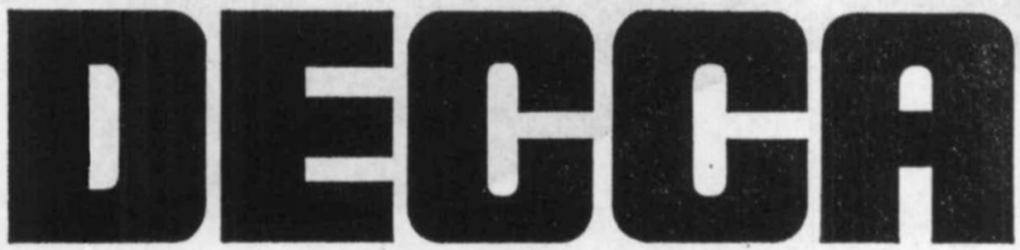

Radar and Navigation aids

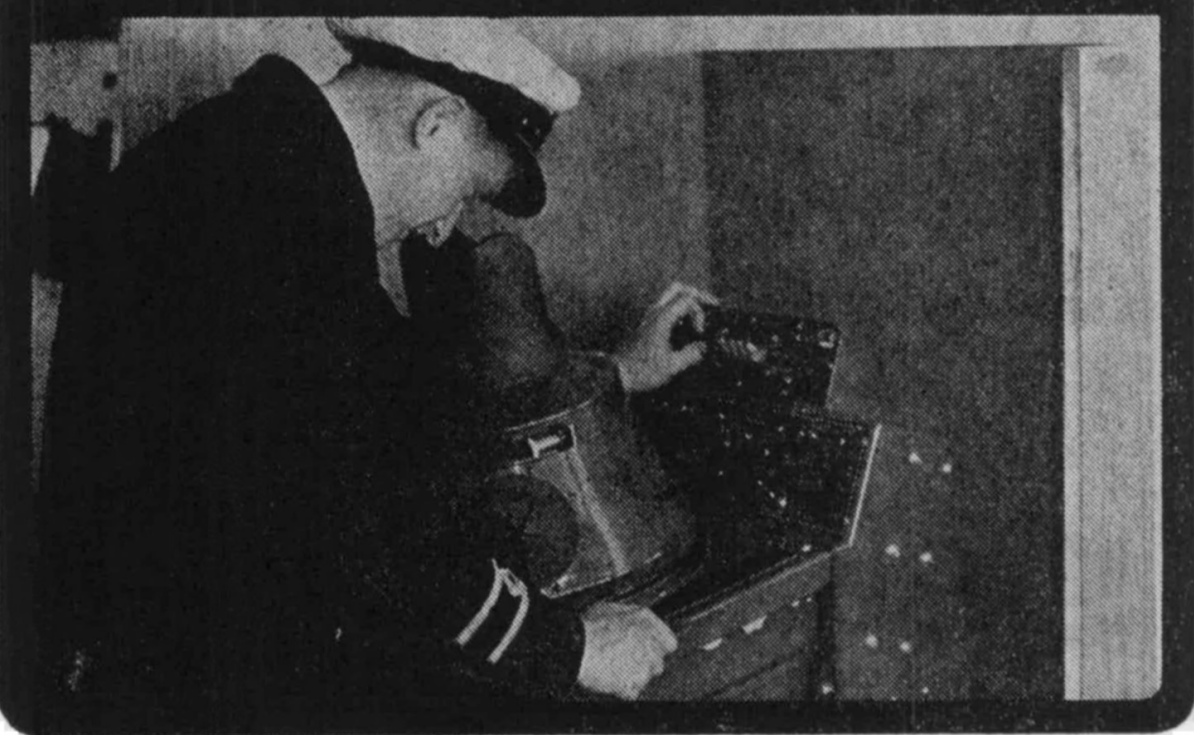

The Decca Navigator Company Ltd Decce Radar Ltd London. 


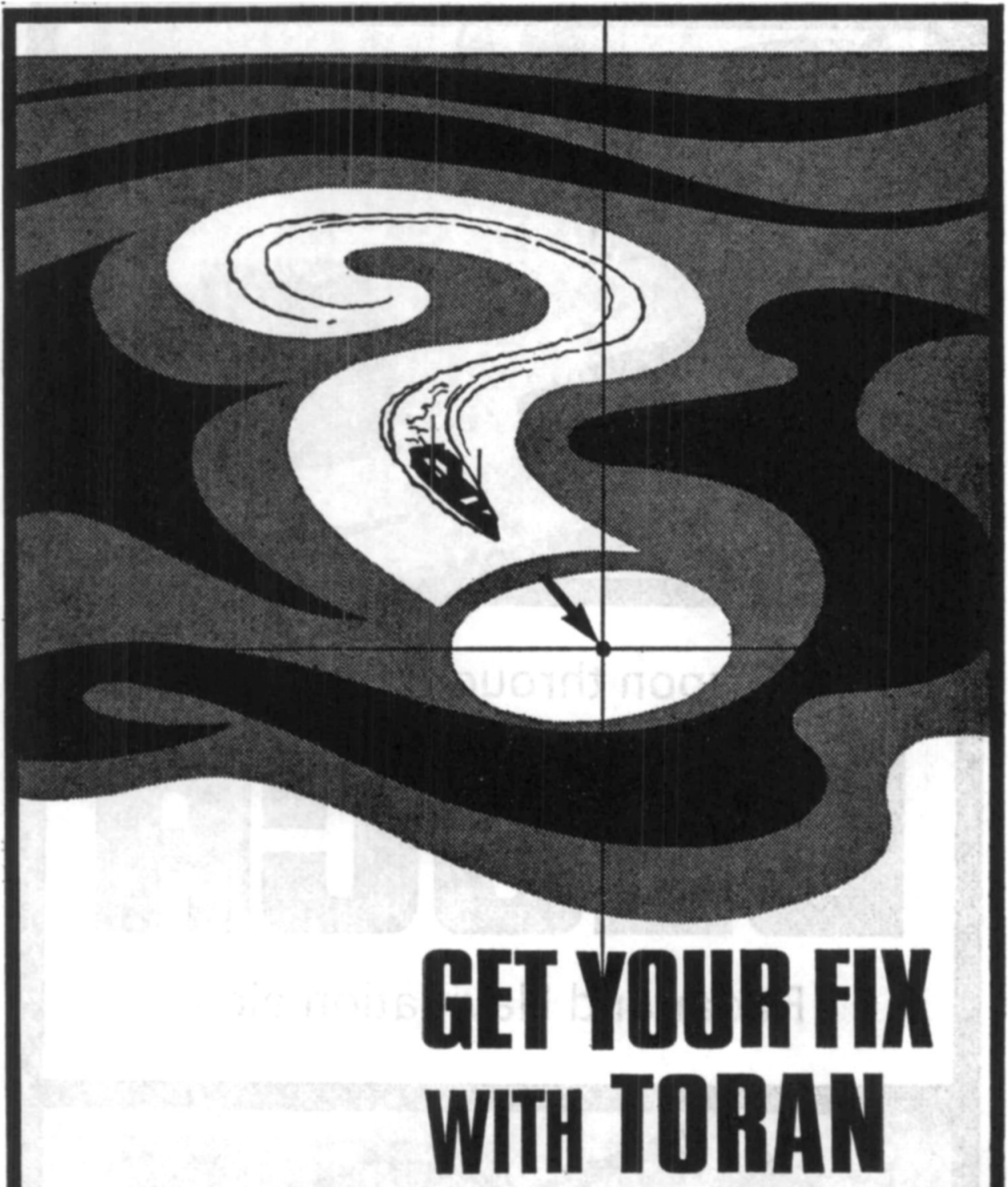

Accuracy between 1 and 10 metres

P. 10 CHAIN : $50 \mathrm{~km}$ range for Sounding, Dredging, Port conservancy

P. 100 CHAIN, $700 \mathrm{~km}$ range for Oil exploration, Hydrography, Oceanography TORAN "O": $1200 \mathrm{~km}$ range-range for Airborne and Geophysical surveys, Oceanology 


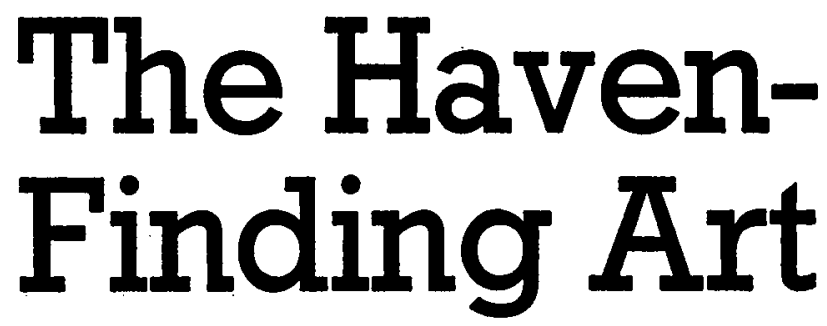

A History of Navigation from Odysseus to Captain Cook

New augmented edition

\section{E. G. R. TAYLOR}

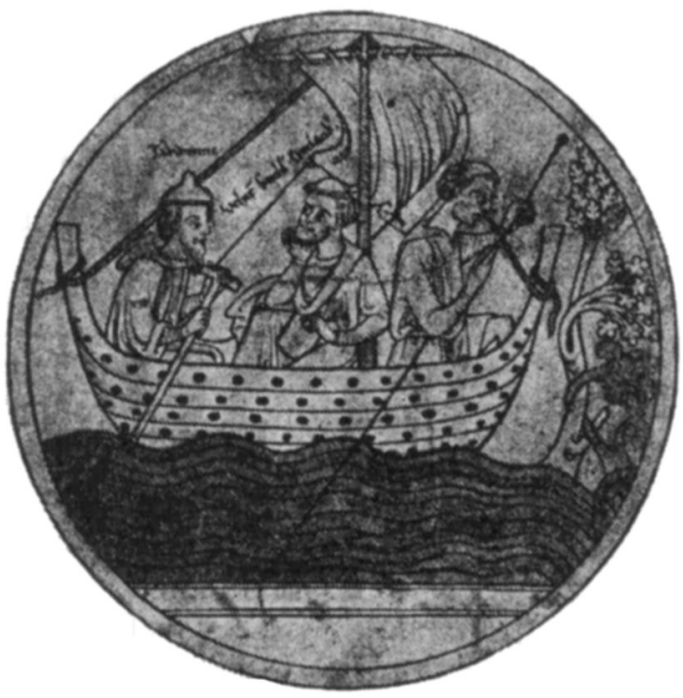

In this book the haven-finding art is traced from its first crudities and dangers, through one line of invention or line of advance after another, until at last mathematical precision was reached. This new edition, with an appendix on early Chinese navigation based on the research of Joseph Needham, F.R.S., is published in association with the Institute of Navigation.

- A better book on the art of navigation down to Captain Cook's days has not yet been written in the English language (and I know of none so succinct, authoritative and informative in any foreign language) ... It fulfils admirably a long-felt need among all English seafarers.' MARINER'S MIRROR 320 pages. Illustrated. $£ 2 \cdot 50$ (Members £2)

\section{HOLLIS \& CARTER}




\section{SAFETY AT SEA}

\section{AUTRONICA TRANSISTORISED ELECTRONIC BEACONS}

These lights are being used all over the world to ensure the safe and efficient movement of goods from origin to destination, marking rocks, headlands, wharves and shipping lanes.

For long endurance, low price and thorough reliability, AUTRONICA beacons are being used extensively either from electrical mains or off batteries with a durability of one to two years.

Full particulars from

\section{LOSEBERRY ENTERPRISES}

Rear-Admiral (Ret.) A. L. P. Mark-Wardlaw,

Loseberry, Claygate, Surrey, England. Telephone : Esher 62882.

\section{'NAVIGATION'}

NA VIGATIOON (Paris), the quarterly Journal of the French Institute of Navigation, is available to Members of the Institute at the preferential subscription rate of $£ 2.00$ per annum. Subscriptions should be addressed to the Institute office in London.

The July 197 I number includes a paper by Van Etten on low frequency and very low frequency navigation systems; a description of 'Navstar'; an appreciation by Manuali of the usefulness of satellites for civil aviation and merchant marine navigation; a paper on time routes under sail; an article on Arab navigation in the Indian Ocean; some notes on weather routing; and an article on the discovery of the Jacob's Staff.

In addition there is, as usual, a record of navigational interest, reviews and correspondence. 


\section{Marconi complete naval communications}

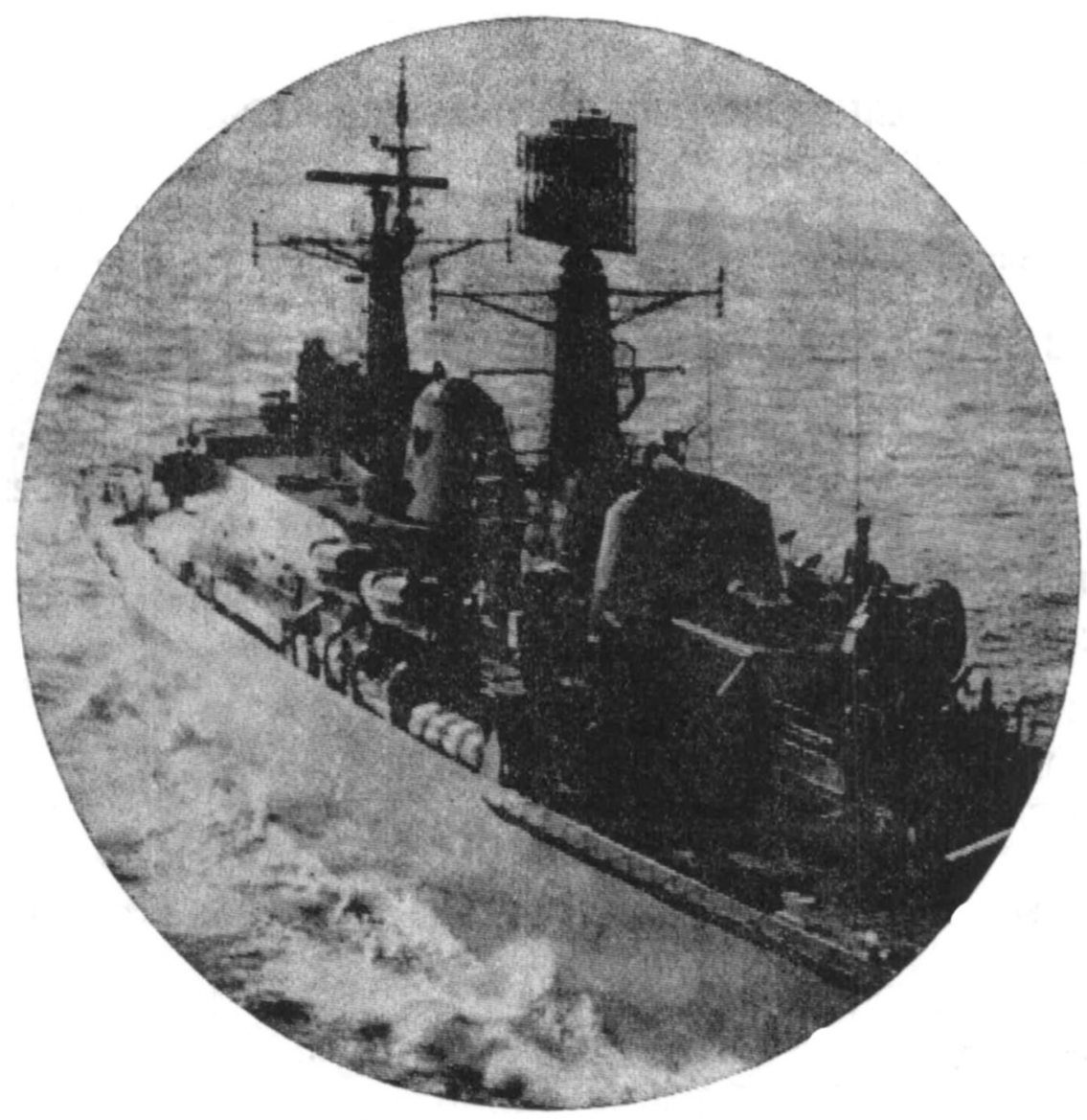

The Marconi comprehensive range of s.s.b/i.s.b naval communications equipment meets all present and foreseeable requirements for voice and automatic telegraphy.

The complete range conforms to Royal Naval standards of resistance to shock, vibration and climatic conditions, and has been NATO codified by the British Defence Department. It is in wide use by the Royal Navy and in the modernization of ten other navies.
Marconi Communication Systems Limited also has a complete range of communications equipment available for shore stations; shipborne, mobile and static space communication earth terminals; digital transmission, and airborne communications.

In addition the Company is able to assist naval departments and shipbuilders with the planning, fitting, testing and tuning of complete ship communications installation.

\section{Marconl Communication Systems Limitod}

Radio Communications Division, Chelmsford, Essex 


\section{USEFUL BOOKS ON NAVIGATION}

\section{AND SHIPPING LAW}

NIGHOLLS'S SEAMANSHIP AND NAUTIGAL KNOWLEDGE

By CHARLES H. BROWN, F.R.S.G.S. Extra Master £3.50

Per post $£ 3.75$

Supplement 20p

Per post 221 1 p

BASIO SEAMANSHIP (FOR BEgINNERS AT SEA)

By COMMANDER PETER CLISSOLD, R.N.R. (Rtd.)

$$
£ 1.05
$$

Supplement 20p

Per post $£ 1 \cdot 12 \frac{1}{2}$

Per post 221 $\frac{1}{2}$

\section{RADAR OBSERVER'S HANDBOOK}

By WILLIAM BURGER, M.Sc. (Wales) Extra Master $£ 2 \cdot 10$

Per post $£ 2 \cdot 20 \frac{1}{2}$

\section{BUSINESS AND LAW FOR THE SHIPMASTER}

By CAPTAIN F. N. HOPKINS, M.I.N., Extra Master $\$ 4 \cdot 50$

Supplement 25p

Per post $£ 4.74$

Per post 27p

\section{MERGHANT SHIPPING AGTS}

Revised by CAPTAIN W. V. J. CLARKE, D.S.C.

$$
\text { £3.00 }
$$

Per post $£ \mathbf{3 . 2 4}$

SHIPBROKERS AND THE LAW

By E. J. EDWARD, Ld.B. (Lond.)

$$
£ 1 \cdot 50
$$

Per post $£ 1 \cdot 60 \frac{1}{2}$

\section{LAW AND PRAGTIGE OF SEA TRANSPORT}

By CAPTAIN L. F. H. STANTON, A.M.Inst.T.

$$
£ 3.15
$$

Per post $\mathbf{£ 3 . 5 4}$

Catalogue " $N$ ", giving further titles and details, free on request.

\section{BROWN, SON \& FERGUSON, LTD.,}

52 DARNLEY STREET, GLASGOW, S.1. 


\section{DIGIPLOT...

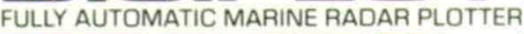 TESTED AT SEA}

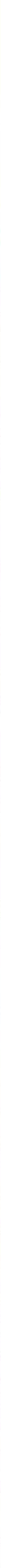

